\title{
Okul Öncesindeki Suriyeli ve Türk Çocukların Oyunları ve Oyundaki İlişkileri
}

\author{
Betül YANIK ÖZGER ${ }^{1}$ Handenur KOZANDAĞI
}

- Geliş Tarihi: 31.01.2020 • Kabul Tarihi: 18.05.2020 • Çevrimiçi Yayın Tarihi: 13.10.2020

\section{$\ddot{\mathbf{O z}}$}

$\mathrm{Bu}$ çalışmada, bir okul öncesi sınıfındaki Suriyeli ve Türk çocukların oyunları, bu oyunlarda kurdukları ilişkiler ve bu süreçte rol oynayan unsurlar araştırılmıştır. Etnografik durum araştırması olarak tasarlanan bu araştırma Kahramanmaraş ilinin merkezinde bulunan bir ana sınıfında 5-6 yaşlarındaki 18 çocuk ve 8 ebeveynin katılımıyla gerçekleştirilmiştir. Veriler üç ay boyunca araştırmacılardan birinin kendi sınıfında gözlem, görüşme, doküman analizi ve araştırmacı günlüğü kullanılarak toplanmıştır. Elde edilen veriler içerik analizi yöntemiyle çözümlenmiştir. Araştırma sonucuna göre Suriyeli ve Türk çocuklar beden dilini kullanarak oluşturdukları oyunlarda ilişkilerini ilerletmiş ve Suriyeli bir kız çocuğunu oyunlarda lider olarak kabul etmişlerdir. Türk ve Suriyeli çocuklar arasındaki ilişkiler zamanla yakın arkadaşlıklara dönüşürken, bazı çocuklar arasında sosyal dışlamalar da yaşanmıştır. Çocukların oyundaki ilişkilerini şekillendiren unsurlar ise öğretmenin ve ailelerin çocuklara yönelik yaklaşımları olmuştur.

Anahtar sözcükler: Suriyeli çocuklar, okul öncesi eğitim, oyun, etnografik araştırma

Atıf:

Yanık Özger, B. ve Kozandağı, H. (2021). Okul öncesindeki Suriyeli ve Türk çocukların oyunları ve oyundaki ilişkileri. Pamukkale Üniversitesi Eğitim Fakültesi Dergisi, 51, 299326.doi:10.9779/pauefd.682823.

\footnotetext{
* Bu çalışma, 6. Uluslaraarası Okul Öncesi Eğitimi kongresinde 2-5 Ekim 2019 tarihleri arasında sözlü bildiri olarak sunulmuştur.

** Dr.Öğrt.Üyesi, Kahramanmaraş Sütçü İmam Üniversitesi, Eğitim Fakültesi, yanikbetul@ hotmail.com, ORCID: 00000001-7524-9159

***Öğretmen, MEB Ökkaş Gümüşer Ortaokulu, handekozandagi@ gmail.com, ORCID: 0000-0001- 8539-7366
} 


\section{Giriş}

Mülteci çocuklar, birçok ülkenin üzerinde önemle durduğu konuların başında gelmektedir. $\mathrm{Bu}$ ülkeler arasında yer alan Türkiye, bir milyondan fazla Suriyeli mülteci çocuğa ev sahipliği yapmaktadır (Milli Eğitim Bakanlığı, 2018). Birleşmiş Milletler Çocuk Hakları Sözleşmesine göre bütün çocuklar din, dil ve irk fark etmeksizin hayatta kalma, korunma ve gelişme olmak üzere belli başlı temel haklara sahiptirler. Ülkelerden beklenen, diğer bütün çocuklar gibi mülteci çocukların da temel haklarını gözetmeleri ve sahip oldukları bu yükümlülükleri yerine getirmeleridir (UNICEF, 2007).

Türkiye, sayıları gün geçtikçe artan Suriyeli çocuklara yönelik çalışmalarını sürdürmekte ve bu çocukların eğitimine yönelik önemli adımlar atmaktadır (Gencer, 2017). Milli Eğitim Bakanlığı (MEB) daha önce açmış olduğu Geçici Eğitim Merkezleri ile Suriyeli çocuklara eğitim firsatı sunarken şimdilerde ise devlet okullarında bu eğitimi devam ettirmektedir. Diğer yandan Aile, Çalışma ve Sosyal Hizmetler Bakanlığı ile yürütülen protokolle Suriyeli çocukları eğitim sürecine dâhil etmeyi sürdürmektedir (Tatlıcıoğlu, 2019). Yürütülen bu çalışmalar, mülteci çocukların okula kazandırılmasında, yeterli olmasa da, önemli katkılar sunmaktadır. Ancak Suriyeli çocuklara sunulan eğitimin niteliği ve planlanmasındaki eksiklikler bu süreçteki kritik sorunların başında gelmeye devam etmektedir (Özer, Komşuoğlu ve Ateşok, 2016).

Eğitim kurumlarının, mülteci çocukların okul içerisinde etkin şekilde katılımlarını ve karşılaştıkları problemleri çözmesi bakımından önemli bir rolü bulunmaktadır (Kardeş, 2018; Sakız, 2016). Özellikle eğitimin ilk basamağı olan okul öncesi eğitim, mülteci çocukların akademik ve sosyal becerilerinin gelişmesine katkı sağlayarak topluma uyumlarını kolaylaştırmada köprü görevi görmektedir (Lunneblad, 2017; Prior ve Niesz, 2013; Schachner, 2017). Ancak Türkiye gibi birçok ülkenin mülteci çocukların okula uyumlarını sağlayıcı ve bütünleştirici bir eğitim sistemine sahip olmaması (Kağnıc1, 2017; Karakuş, 2019; UNICEF, 2016; Yanık Özger ve Akansel, 2019 ) ve öğretmenlerin mülteci çocukların eğitimi ile ilgili bilgi ve donanım yönünden eksik olmaları (Bačáková, 2011; Sağlam ve Kanbur, 2017; Shriberg, 2010) mülteci çocukların eşit ve kaliteli eğitim alma olanağını ortadan kaldırmaktadır.

Mülteci çocuklarla ilgili yapılan araştırmalara bakıldığında çocukların travmatik deneyimleri ve zihinsel sağlı̆̆ gibi tek yönlü psikolojik çalışmalar üzerinde yoğunlaşıldığı görülmektedir (Rutter, 2006; Taylor ve Sidhu, 2012). Eğitimsel perspektiften ise mülteci 
B. Yanık Özger ve H, Kozandağı / Pamukkale Üniversitesi Eğitim Fakültesi Dergisi, 51, 299-326, 2021301 çocuklarla ilgili çalışmaların az olduğu, var olan çalışmaların ise ergenlerle ya da ikinci dil edinimi ile ilgili araştırmalar olduğu anlaşılmaktadır (Alba, 2013). Pinson ve Arnot (2007), mültecilerle ilgili eğitim araştırmalarının gençlere ve onların öğretmenlerine yönelik pratiksel tavsiyelerle sınırlandırıldığını vurgulamaktadır. Mosselson (2006), araştırmaların mülteci çocukların okuldaki algılarını ve onların okula nasıl adapte olduklarını açıkladığını fakat bu açıklamaların onlara sorularak gerçekleştirilmediğini vurgular. Özellikle küçük yaştaki mülteci çocukların seslerini duyuracak çalışmaların sayısı yok denecek kadar azdır (Maurice ve Roßbach, 2017; Prior ve Niesz, 2013).

Rogoff (2003), ırk, etnik ve dil olarak farklılığa sahip olan çocuklar arasındaki etkileşimi anlamada kültür ve insan gelişimi kuramını işaret eder. Farklı kültüre sahip yetişkin ve çocuklar aynı kültürel toplumun içerisindeki etkinliklere katılmasıyla benzer sosyal etkileşim biçimi ve stilleri geliştirmektedir. Rogoff'un (2003) teorisine göre, bireyin gelişimi sosyokültürel aktiviteler içerisindeki katılımcı rolünün değişimiyle gerçekleşmektedir. Çocukların birbiriyle olan etkileşim ve bağlantısının yüksek olduğu sosyokültürel aktivitelerden birisi oyundur. Oyun, farklı kültüre sahip olan çocukların birbiriyle ilişki kurmalarında, kendi dillerini, kurallarını ve değerlerini oluşturmada önemli bir yere sahiptir (Gleave ve Cole-Hamilton, 2012). Mülteci ve ev sahibi konumundaki çocukların birlikte oyun oynamaları kültürel farklılıkların üstesinden gelmelerine ve grubun bir parçası olmalarına yardımcı olur. Bjorck-Akesson ve Brodin’e göre (2005) göre oyun, mülteci çocukların yeni kültüre uyum sağlamasında ve dil ediniminde kolaylık sağlamaktadır. Mülteci çocuklar için tedavi amaçlı da kullanılan oyunlar, çocukların güçlüklerle baş etmesinde etkili bir yöntem olarak görülmektedir (Eslek ve Irmak, 2018). Buradan yola çıkıldığında Türkiye'deki okul öncesi çağındaki mülteci çocukların diğer çocuklarla olan deneyimleri ve ürettikleri sosyal ilişkileri anlamamızda oyun temel bir araçtır.

$\mathrm{Bu}$ araştırmanın amacı bir okul öncesi sınıfındaki Suriyeli ve Türk çocukların oyunlarını, bu oyunlarda kurdukları ilişkileri ve bu süreçte rol oynayan unsurları anlamaktır. $\mathrm{Bu}$ nedenle çocukların kendi aralarında ürettikleri oyunlar doğal ortamlarında uzun bir zaman diliminde gözlemlenmiştir. Bu araştırma iki açıdan önem teşkil etmektedir. İlki mülteci çocukların seslerini bize doğrudan veren ve değişimlerini sosyokültürel süreç üzerinden gösteren etnografik yöntemin kullanılmasıdır. İkinci olarak Türkiye'deki okul öncesi çağındaki mülteci çocuklarla ilgili sınırlı olan alan yazına katkı sunmasıdır. Bu amaç doğrultusunda aşağıdaki sorulara yanıt aranmıştır: 
- Bir okul öncesi sınıfindaki Suriyeli ve Türk çocukların oyunları nasıldır?

• Bir okul öncesi sınıfındaki Suriyeli ve Türk çocukların oyundaki ilişkileri nasıldır?

- Bir okul öncesi sınıfındaki Suriyeli ve Türk çocukların oyunlarında rol oynayan unsurlar nelerdir?

\section{Yöntem}

\section{Araştırma Modeli}

$\mathrm{Bu}$ araştırma, etnografik durum araştırması şeklinde tasarlanmıştır. Durum araştırması, zaman ve mekânla sınırlandırılmış bir programın, bir kişi, bir sosyal olgunun detaylı olarak betimlenip analiz edilmesidir (Merriam, 2015). Etnografik durum çalışması ise belirli mekân ve zaman dilimi içerisinde doğal ortamında yapılan uzun gözlemler olarak tanımlanır (Erickson, 1984; Yin, 2003). Bu araştırmada etnografik durum araştırmasının tercih edilmesindeki neden Suriyeli ve Türk çocukların oyunlarını ve oyundaki ilişkilerini anlamada doğal ve uzun zaman dilimini kapsayan gözlemlere ihtiyaç duyulmasıdır. Etnografik yöntem, küçük çocukların bakış açılarını ve seslerini duyurmada önemli bir yöntem olarak görülmektedir (Hoyte, Torr ve Degotardi, 2014). Bu araştırmada da çocukların kendi aralarında ürettikleri oyunlara ve bu süreçte kurdukları ilişkilere odaklanılarak bakış açıları ortaya konmuştur. Bu çalışma, araştırmacılardan biri olan Handenur Kozandağı'nın (araştırmadaki öğretmen) kendi sınıfında gerçekleşmiştir. Bu durum araştırmacıların çocukların ürettikleri bütün oyunları ve ilişkileri doğal ortamında uzun bir zaman diliminde görebilmesini sağlamıştır.

\section{Çalışma Grubu}

$\mathrm{Bu}$ araştırmanın çalışma grubunu oluşturan katılımcılar amaçlı örnekleme türlerinden uygun örneklemeye göre belirlenmiştir (Merriam, 2015). Buna göre Suriyeli mülteci çocukların yoğun olarak bulunduğu il ve okul tercih edilmiştir. Araştırmacılardan birinin bu okulda çalışıyor olması da çalışma grubunu belirleyen unsur olmuştur.

$\mathrm{Bu}$ araştırma, Kahramanmaraş ilinin merkez ilçelerinden birisine bağglı ortaokul bünyesindeki bir anasınıfında gerçekleşmiştir. Dört katlı tek bir binadan ve geniş bir bahçeden oluşan okulda okul öncesi sınıfı binanın giriş katında yer almaktadır. İki sınıftan oluşan okul öncesinde bir koridor ve bu koridorda çocuk lavaboları bulunmaktadır. Çocuklar sabah ve öğle olmak üzere ikili şekilde eğitim görmektedirler. 
B. Yanık Özger ve H, Kozandağı / Pamukkale Üniversitesi Eğitim Fakültesi Dergisi, 51, 299-326, 2021303

Okulun bulunduğu bölge düşük ücretle çalışan insanların yaşadığı ve geçimin fabrika veya inşaat işçiliğinden sağlandığı yerlerden birisidir. Göçle birlikte okulun bulunduğu mahalle Suriyeli mültecilerin yaşam alanı haline gelmiş ve sınıflardaki Suriyeli çocuk sayısı günden güne artmıştır. Araştırmaya katılımcı olarak beş ve altı yaşındaki 18 çocuk ve 8 aile (ailelerden 3'ü Suriyeli, 5'i Türk) katılmıştır. Çalışma grubunun özellikleri aşağıdaki tabloda gösterilmiştir:

Tablo 1. Çalışma Grubunun Özellikleri

\begin{tabular}{|c|c|c|c|c|c|c|}
\hline Kod İsim & Cinsiyet & Köken & $\begin{array}{l}\text { Türkçe } \\
\text { Konuşabilme }\end{array}$ & $\begin{array}{l}\text { Türkiye'ye Geliş } \\
\text { Y1lı }\end{array}$ & $\begin{array}{l}\text { Kardeş sayısı } \\
\text { Yeri }\end{array}$ & Doğum \\
\hline Rand & $\mathrm{K}_{1 \mathrm{z}}$ & Suriye & Konuşamiyor & 2017 & 4 & Suriye \\
\hline Ayten & $\mathrm{K}_{1 \mathrm{Z}}$ & Suriye & Konuşamıyor & 2012 & 4 & Türkiye \\
\hline Henedi & $\mathrm{K}_{1 \mathrm{z}}$ & Suriye & Konuşamıyor & 2012 & 4 & Türkiye \\
\hline Fatma & $\mathrm{K}_{1 \mathrm{z}}$ & Suriye & Konuşamıyor & 2014 & 3 & Suriye \\
\hline Beşşar & Erkek & Suriye & Konuşamıyor & 2012 & 5 & Türkiye \\
\hline Merva & $\mathrm{K}_{1 \mathrm{z}}$ & Suriye & Konuşamıyor & 2012 & 4 & Türkiye \\
\hline Emir & Erkek & Türk & - & - & 3 & - \\
\hline Ali & Erkek & Türk & - & - & 3 & - \\
\hline Mustafa & Erkek & Türk & - & - & 2 & - \\
\hline Yusuf & Erkek & Türk & - & - & 2 & - \\
\hline Mevlüt & Erkek & Türk & - & - & 3 & - \\
\hline Eren & Erkek & Türk & - & - & 2 & - \\
\hline Oğuz & Erkek & Türk & - & - & 3 & - \\
\hline Hatice & $\mathrm{K}_{1 \mathrm{z}}$ & Türk & - & - & 2 & - \\
\hline Ebrar & $\mathrm{K}_{1 \mathrm{z}}$ & Türk & - & - & 3 & - \\
\hline Ela & $\mathrm{K}_{1 \mathrm{z}}$ & Türk & - & - & 3 & - \\
\hline Azra & $\mathrm{K} 1 \mathrm{z}$ & Türk & - & - & 2 & - \\
\hline Nurdan & $\mathrm{K}_{1 \mathrm{Z}}$ & Türk & - & - & 2 & - \\
\hline
\end{tabular}

Tablo 1'e göre araştırmaya katılımcı olan çocuklardan 6'sı Suriyeli ve 12'si Türk'tür. 6 Suriyeli çocuktan yalnızca 1'i erkek ve 5'i kız olurken, Türk çocuklarda 7'si erkek, 5'i kızdır. Suriyeli çocuklardan hiçbiri Türkçe konuşamazken, çocukların Türkiye’ye geliş yılları 2012-2017 arasında değişmektedir. 


\section{Veri Toplama Araçları ve Süreci}

$\mathrm{Bu}$ araştırmada veri toplama araçları olarak görüşme, gözlem, doküman analizi ve sesligörsel materyaller kullanılmıştır.

Gözlem, araştırmacının bireylerin etkinlikleri ve davranışlarına ilişkin alan notları tutmasını içermektedir (Creswell, 2018; Merriam, 2015). Bu araştırmada da Suriyeli ve Türk çocukların oyunları ve bu oyunlarındaki ilişkilerini anlamak için gözlem yöntemine başvurulmuştur. Gerçekleştirilen gözlemler, yapılandırılmamış alan notları tutularak ve oyun sırasında video kaydı alınarak elde edilmiştir. Gözlemler 2019'un Şubat ayından Nisan ayının sonuna kadar 3 ay boyunca devam etmiştir.

Veri toplama tekniklerinden görüşme ise yarı yapılandırılmış ve yapılandırılmamış şeklinde iki türlü gerçekleştirilmiştir. Yarı yapılandırılmış görüşmelerdeki sorular, gözlem verilerinden ve mülteci çocukların oyunları ile ilgili çalışmalardan yola çıkılarak hazırlanmıştır (MacMillan, Ohan, Cherian ve Mutch, 2015). Yarı yapılandırılmış görüşmeler farklı zamanlarda iki araştırmacı tarafından iki kez gerçekleştirilmiştir. İlk görüşme Mayıs ayında 15 çocuk ve 8 aileyle ses kaydı alınarak gerçekleşmiştir. İkinci görüşme ise iki hafta sonra yalnızca çocuklarla yapılmıştır. Yapılandırılmamış görüşmeler ise gözlem esnasında sohbete dayalı kurulan diyaloglar olmuştur. $\mathrm{Bu}$ araştırmada yarı yapılandırılmış görüşme tekniğinin iki kez gerçekleştirilmesindeki amaç gözlemlerin geçerliliğini teyit ederek çocukların ilişkilerini kendilerinden dinlemektir. Suriyeli çocuklar ve aileleriyle yapılan görüşmeler, aynı okulda görev yapan ve iyi derecede Türkçe bilen Suriyeli öğretmenin tercümanlığıyla yürütülmüştür. Bu görüşmeler daha sonra Arapça Mütercim Tercümanlık Bölümü mezunu olan ikinci bir kişi tarafından kontrol edilmiştir.

Veri toplama tekniklerinden doküman analizi ise çocukların yapmış oldukları resimler ve araştırmacı günlüğünden oluşurken, sesli-görsel materyaller arasında çocukların oyun sırasında çekilen videoları ve fotoğrafları yer almıştır.

\section{Veri Analizi}

$\mathrm{Bu}$ araştırmada elde edilen veriler içerik analizi yöntemiyle çözümlenmiştir. Bu veri analizinde verilerin kodlanması, kodların bir araya getirilmesi ve temalara indirgenmesi şeklinde işlem basamakları takip edilmiştir (Creswell, 2018). Buna göre bu araştırmada ham veriler 30 sayfa gözlem notu, 28 adet ses kayd1, 66 adet fotoğraf, 10 adet video, 55 adet çocukların çizimleri ve 18 sayfa araştırmacı günlüğüdür. Analizin ilk aşaması bütün verilerin 
B. Yanık Özger ve H, Kozandağı / Pamukkale Üniversitesi Eğitim Fakültesi Dergisi, 51, 299-326, 2021305 kodlanma süreciyle başlamıştır. İlk olarak ham veriler arasından ses kayıtları ve videolar yazılı doküman haline getirilmiş ve bütün veriler baştan sona kodlanmıştır. Kodlama sonucunda 198 adet kod oluşturulmuştur. Oluşturulan bu kodlar kendi içerisinde anlamlı ve ilişkili olacak şekilde bir araya getirilerek 14 tane kategorik kod elde edilmiştir. Bu işlemden sonra kategorik kodlar da kendi içerisinde anlamlı olacak şekilde bir araya getirilerek genel başlıklar altında toplanmış ve 4 adet tema elde edilmiştir. Bu temalar; ilişki ve iletişim, oyunlar, öğretmenin yaklaşımı ve aileler şeklinde isimlendirilmiştir. Oluşturulan bu temalar arasında bağlantılar kurulmuş ve araştırma soruları altında organize edilmiştir.

\section{Araștırmacıların Rolü}

$\mathrm{Bu}$ çalışmanın ortaya çıkmasında iki araştırmacının dezavantajlı bölgelerdeki çocukların yaşantılarını ve eğitim içerisindeki sorunlarını anlama isteği yatmaktadır. Bu durum iki araştırmacının bir okulda tanışmasını sağlamış ve bu araştırmanın doğmasına vesile olmuştur.

Araştırmacılardan Handenur Kozandağı çalışma süresince öğretmen ve araştırmacı pozisyonunu korumuştur. Yedi yıllık öğretmenlik deneyimi bulunan araştırmac1, Suriyelilerin yaşadığı bir mahallede okul öncesi öğretmeni olarak yıllardır çalışmaktadır. Bu süreçte Suriyeli çocuklar ve aileleriyle önemli tecrübeler edinmiştir. Önceki yıllarda sınıfında Türkçe bilmeyen Kürt çocukların varlığı da bu deneyimi destekleyen unsur olmuştur. Kürtçe ve Arapça dilindeki temel kelimeleri öğrenmiş fakat bunun yanında okuldaki Türkçe bilen Suriyeli öğretmenden de destek almıştır. Öğretmenlik süresince çocukların ilişkilerine çok müdahale etmemiş ve aşırı kuralcı öğretmen profilinden uzak durmuştur.

Araştırmacılardan bir diğeri olan Betül Yanık Özger, okul öncesi öğretmenliği yaptığı on yıl boyunca çocukların akran kültürüne odaklanmış ve birçok etnografik çalışmalar yürütmüştür. Bu araştırmada veri toplama, analiz etme ve raporlaştırma sürecinde rolü bulunmuştur.

\section{Geçerlilik ve Güvenirlilik}

Nitel araştırmalarda geçerlilik ve güvenirliliğin sağlanmasında takip edilmesi gereken kriterler bulunmaktadır. Bunlardan ilki araştırmayla ilgili etik kuralların yerine getirilmesidir (Glesne, 2012). Bu araştırmada da çocukların ailelerinden izin alınmış ve çalışma süreci hakkında bilgi verilmiştir. Çocukların ve ailelerin gizliliğini korumak adına gerçek isimler 
yerine kod isimler kullanılmıştır. Diğer yandan araştırmanın okulda yapılıyor olmasından ötürü bütün yasal izinler alınmıştır.

Etik önlemlerin yanı sıra nitel bir araştırmada bulguların geçerliliği ve güvenirliliği; inandırıcılık, aktarılabilirlik, tutarlılık ve teyit edilebilirliğin uygulanmasıyla gerçekleşmektedir (Lincoln ve Guba, 1985). Bu çalışmada verilerin geçerliliği ve güvenirliliği uzun gözlemler, yoğun betimlemeler, katılımcı teyidi, anlaşılabilir bir dil kullanımı ve üçgenleme yapılarak sağlanmıştır. Verilerin güvenirliliği için kodlayıcılar arasındaki tutarlılığa bakılmış ve iki araştırmacının yapmış oldukları kodlamalar incelenmiştir. Miles ve Huberman (1994), nitel bir güvenirlilik için kodlayıcılar arasındaki uyumun en az .70 olması gerektiğini belirtmiştir. Bu araştırmadaki iki kodlayıcı arasındaki uyum .90 olarak hesaplanmıştır.

\section{Bulgular}

$\mathrm{Bu}$ bölümde araştırmada elde edilen bulgulara yer verilmiştir. Buna göre bu araştırmada Türk ve Suriyeli çocuklar beden dilini kullanarak oluşturdukları oyunlarda ilişkilerini ilerletmişler ve Suriyeli bir kız çocuğunu oyunlarda lider olarak kabul etmişlerdir. Bazı Türk ve Suriyeli çocuklar arasındaki ilişkiler zamanla yakın arkadaşlıklara dönüşürken, çocuklar arasında sosyal dışlamalar da yaşanmıştır. Çocukların oyundaki ilişkilerini şekillendiren unsurlar ise öğretmenin ve ailelerin çocuklara yönelik yaklaşımları olmuştur.

\section{Türk ve Suriyeli Çocukların Oyunları}

Okulun ilk zamanlarında Suriyeli ve Türk çocuklar aynı oyun içerisinde yer almamış ve oyun kurma girişiminde bulunmamışlardır. Fakat ilk dönemin sonlarına doğru Suriyeli ve Türk çocuklar kısa süreli de olsa birbirlerinin oyunlarına katılmaya başlamışlardır. Bu süreç okulun ikinci dönemiyle birlikte daha da ilerlemiş Suriyeli ve Türk çocuklar birbirleriyle daha sık oynamaya başlamışlardır. Çocuklar, birbirlerinin dilini bilmediği için basit kuralları olan, izleyip öğrenilebilen oyunlar üretirken, birbirlerine duygularını ifade etmek için jest ve mimiklerden faydalanmışlardır. Oyunlar arasında komik yüz ifadeleri yaparak gülüşme, gıdıklamaca, sarılıp dolaşmaca, balon sektirmece, jimnastik hareketleri yapma, sandalye kapmaca, şarkılı oyunlar, yakalamaç yer almıştır. Bununla ilişkili örnek bir durumu açıklayan gözlem notu aşağıda verilmiştir:

Diğer çocuklar deve-cüce oynarken Hatice ile Merva da kenarda sandalyeye oturmuş gülüşüyorlar. Hatice beresini takmış komiklik yapıyor Merva' ya: Dil çıkarıyor, 
B. Yanık Özger ve H, Kozandağı / Pamukkale Üniversitesi Eğitim Fakültesi Dergisi, 51, 299-326, 2021307

kaşlarını çatıyor, gözlerini şaşı yapıyor. Merva da aynı şekilde komik yüz ifadeleri yapıyor. Birlikte gülüşüyorlar (Gözlem, 12.03.2019).

Suriyeli ve Türk çocuklar oyunlarını öğretmenden bağımsız olarak üretirken, Suriyeli çocuklar bildikleri oyunları Türk çocuklarına öğreterek onları oyunlarına dâhil etmişlerdir. $\mathrm{Bu}$ oyunlarda Türk çocuklar Arapça şarkı eşliğinde Suriyeli çocukların yapmış olduğu hareketleri yapmışlar ve onların şarkılarını söylemeye çalışmışlardır. Bu durumu açıklayan gözlem ve görüşme notları aşağıda verilmiştir:

Çocuklar ele ele tutuşup daire oldular. Sonra Suriyeli çocuklar Arapça şarkı söylemeye başladılar ve Türk çocuklar da bu şarkıyı söylüyormuş gibi yaptılar. Çocuklar birlikte yapmış oldukları daireyi açıp, büzdüler. Ellerini çırpıp önce burunlarını, kulaklarını ve sonra da yanaklarını tuttular (Gözlem, 11.02.2019).

Araştırmacı- Suriyeli arkadaşlarının oyunlarına katıldığında oyunun kurallarını nasıl anliyorsun?

Ela (Türk Çocuk)- Şimdi sandalye kapmaca oynuyorlar, onlar başka müzik söylüyorlar. Ben de onların dediklerini söylüyorum. (Görüşme, 07.05.2019)

Araştırmacı-Çocuğunuz Suriyeli çocuklarla nasıl anlaşıyor?

Emir'in annesi-El işaretleri ile, oyun tarzını mesela eliyle tarif ederek oynuyor.

Araştırmaci-Nasil mesela?

Emir'in annesi-Mesela top oynayalım diyor. "Beşşar top" diyor. O da "Evet" diyor. Sanırım tek tük de anlıyor artık. Önceleri hiç anlamıyordu sonradan sonraya... Veyahut oradan herhangi bir oyuncak gösteriyor. "Şu şekilde yapalım." diye yerde tarif ediyor. Bazen görüyorum rastlıyorum (Görüşme, 03.05.2019).

Türk ve Suriyeli çocukların birbirleriyle iletişimi arttıkça oyunlarının sayısında artış yaşanmış, kız ve erkek çocuklar birbirinden farklı oyunlar oynamaya başlamışlardır. Türk erkek çocukları, Suriyeli erkek çocukla blok oyunları, kovalamaca, birbirine temas etmeden uçan tekme atma, yerde takla atma gibi oyunlar oynarken, kız çocukları birbirleri ile şarkılı oyunlar, gıdıklamaca, mimik yapma oyunları oynamaya başlamışlardır.

\section{Türk ve Suriyeli Çocukların Oyundaki İlişkileri}

Okulun ilk dönemleri Türk ve Suriyeli çocuklar pek fazla iletişim kurmamış ve kendi içlerinde gruplaşarak oynamışlardır. İlerleyen zamanlarda ise çocukların jest ve mimiklerini 
kullanarak iletişime geçtikleri gözlenmiştir. Beden dili, çocuklar arasındaki iletişimi artırmış ve arkadaşlık ilişkisi kurmalarına yardımcı olmuştur. Bununla ilişkili çocuklarla yapılan görüşme ve gözlem notları aşağıda verilmiştir:

Araştırmacı- Türk çocuklarla nasıl arkadaş oldun?

Henedi- Oyun oynarken (Görüşme, 10.05.2019)

Araştırmacı-Suriyeli çocuklardan hiç arkadaşın var mı?

Oğuz-Beşşar.

Araştırmacı-Beşşar' la nasıl arkadaş oldunuz?

Oğuz-Yakalamaç oynarken. Oyunda arkadaş olduk. (Görüşme, 07.05.2019)

Beşşar ve Emir yaklaşık bir saat boyunca hiç sıkılmadan oynadılar. Üzerinde resimler olan kartları üst üste koymuşlar ve sırayla onların hepsini yapıyorlardı. Resimdekini oluşturunca 'Oleeey', 'Bu kez de yaptık!', 'Aaaaaa!' gibi tepkiler veriyorlar, gülerek oyunlarına devam ediyorlardı. Bunların dışında aralarında pek konuşma olmamıştı. (Gözlem, 18.03.2019)

Suriyeli ve Türk çocuklar, beden dillerini kullanarak ilişkilerini ilerletirken, Suriyeli çocuklar arasından Rand oyun içerisinde liderliği üstlenmiştir. Rand, Türk ve Suriyeli çocukların birlikte oynadığı oyunlarda diğer çocukları yönlendirmiş ve oyunları yönetmiştir.

Çoğu zaman oyunu başlatan ve bitiren kişi olmuştur. Türk ve Suriyeli çocuklar oyuna girebilmek için Rand'tan izin almış ve onun oyuna kabul etmesini beklemişlerdir. Bununla ilişkili örnek bir durumu açıklayan gözlem ve görüşme notları aşağıda verilmiştir:

Çocuklar sandalyeleri dizerek sandalye kapmaca oyunu oynamaya başladılar. Türk çocuklardan Azra'da oyuna dâhil olmak istedi ve Rand'a giderek "Ben de oynamak istiyorum" dedi. Rand parmağıyla boş sandalyeyi işaret ederek oturmasını istedi. Şarkı bittiğinde Henedi boş bir sandalyeye oturacakken Rand müdahale ederek oraya Türk çocuklardan Nurdan'ın oturmasını sağladı (Gözlem, 04.02.2019).

Suriyeli çocuklardan Ayten, Beşşar, Fatma ve Rand; Türk çocuklardan Ela, Ebrar ve Hatice bugün yine deve-cüce oynadılar. Ayten sandalyede oturarak çocuklara 'DeveCüce’ yönergesi veriyordu. Fakat Rand onu sandalyeden kaldırdı ve kendisi oturarak yönerge vermeye başladı. Rand oyundan yanan çocukları 'Aaaa!' diyerek parmağıyla işaret ediyor ve çıkmalarını istiyordu. (Gözlem,15.03.2019) 
B. Yanık Özger ve H, Kozandağı / Pamukkale Üniversitesi Eğitim Fakültesi Dergisi, 51, 299-326, 2021309

Araştırmacı-Suriyeli arkadaşlarının oyunlarında kuralları nasıl anlıyorsun?

Hatice-Bir şey anlamıyorum.

Araştırmacı-Onların oyununa katılmak için izin istiyor musun?

Hatice-Evet.

Araştırmacı-Kimden istiyorsun?

Hatice-Merve, Rand. (Görüşme, 07.05.2019)

Oyunda Rand'ın arkadaşları üzerinde kurmuş olduğu bu otorite Türk çocuklardan Ali tarafından pek kabul görmemiştir. Bazı zamanlar Ali, Rand'ın oyununa katılmayarak liderliğini kabul etmek istememiştir. Onun yerine Rand'ın ürettiği oyuna benzer bir oyun üretmiş ve diğer çocukları kendi oyununa çekmek istemiştir. Bununla ilişkili örnek bir durumu açıklayan gözlem notu aşağıda verilmiştir:

Rand, arkadaşlarıyla birlikte 'Ah Benim Turnam' oyunu oynatıyor ve yönetiyordu. Ali, Rand'ın oyununa katılmak istemeyerek çok benzer bir oyun başlattı. Türk erkek çocuklarının elinden tutarak daire oluşturdu ve "Terazi lastik jimnastik" tekerlemesini söylemeye başladı (Gözlem, 11.02.2019).

Ali, Rand'ın oyun içerisindeki üstünlüğünü kabul etmese de sınıftaki diğer Türk çocuklar bu durumu kabullenmişlerdir. Türk çocuklar, oyunda yaşadıkları sorunu, Arapça bilmeyen öğretmenin yerine, arkadaşları Rand' a şikâyet etmiş ve onun çözmesini istemişlerdir. Türk çocuklarında olduğu gibi Suriyeli çocuklar da aynı şekilde şikâyetlerini Rand'a iletmişlerdir. Rand, Türkçe bilmemesine rağmen çocukları dinlemiş, onları teselli etmiş ve el kol hareketleriyle yönlendirmiştir. Bazı zamanlar ise kendisine gelen şikâyetleri sözcülük yaparak öğretmene anlatmaya çalışmıştır. Rand'a arkadaşlarıyla olan bu ilişkisi sorulduğunda "Arkadaşlarıma yardım etmeyi çok seviyorum. O yüzden bana geliyorlar" şeklinde ifade etmiştir. Bununla ilişkili örnek bir durumu açıklayan gözlem notları aşağıda verilmiştir:

Suriyeli Fatma ve Merva oyun hamuru ile oynuyorlardı. Fatma Merva' nın hamurunu izinsiz almıştı. Merva sinirlendi ve "Raaaand! Raaaand!" seslenerek Rand' 1 çağırdı. Rand hemen kızların yanına gitti. Merva, Arapça kızgın ve yüksek bir ses tonuyla Fatma'yı Rand' a şikâyet etti. Rand Merva'yı dinledikten sonra sakin bir şekilde Fatma'yı uyardı. Fatma, Merva' nın hamurunu geri verdi (Gözlem, 25.04.2019). 
Türk çocuklardan Ebrar ve Azra sandalyeye oturuyorlardı. O sırada Ebrar'ın eli Azra'nın gözüne değdi. Azra eliyle gözünü tutarak bu durumu Rand ile paylaştı. Rand elini Azra'nın omzuna koydu ve onu dinledi. Sonrasında Rand öğretmenin yanına gidip Ebrar'ın Azra'nın gözüne zarar verdiğini beden diliyle anlatmaya çalıştı (Gözlem, 04.02.2019).

Rand'ın Türk çocuklarla kurduğu yakın ilişki, sınıfta tek erkek Suriyeli olan Beşşar tarafından da kurulmuştur. Okulun ilk zamanları Suriyeli kız çocuklarıyla vakit geçiren Beşşar, öğretmenin yardımıyla Türk çocuklarıyla yakınlaşmayı başarmıştır. Bu yakınlaşma zamanla daha da ilerlemiş ve Beşşar Türk erkek çocuklarının arasına kabul edilmiştir. Türk çocuklardan yalnızca biriyle kurduğu arkadaşlık diğer çocukların da onunla arkadaş olmasını sağlamıştır. Bununla ilişkili Türk erkek çocuklarıyla yapılan görüşme notları aşağıda verilmiştir:

Araştırmacı- Suriyeli çocuklardan arkadaşın var mı?

Ali-Var, Beşşar.

Araştırmacı-Nasıl arkadaş oldunuz Beşşar' la?

Ali-Bahçeye çıktığımızda "Okey" diyordu, ben de tamam diyordum. Koştuk, eğlendik.

Araştırmacı- Onu anlamadığında ne yapıyorsun?

Ali- Anlamadığımda şöyle yapıyorum. (Ellerini yanlarda açıyor, dudağını büzüyor)

Araştırmacı- Beş̧̧ar ile arkadaş olmaya nasıl karar verdin?

Ali- Emir arkadaş olmaya başladı, sonra ben de dedim ki: "Ben de kanka olayım bari” dedim. (Görüşme,07.05.2019).

Beşşar, Türk erkek çocuklarıyla arkadaşlık kurduktan sonra Suriyeli kız çocuklarıyla olan oyunlarını azaltmıştır. Türk çocuklarıyla birlikte hamur oynama, kule yapma, arabaları yarıştırma ve birbirlerini kovalamaca türü oyunlar oynamıştır. Yemek sırasında Türk arkadaşlarının yanına oturmayı tercih etmiş ve masada da, ayranı en hızlı içme, oyunlarına devam etmiştir. Türk erkek çocukları Beşşar'ı aralarına kabul etmiş ve oyunlarına katılması için davette bulunmuşlardır. Türk erkek çocukları yerli kültürde "arkadaş" anlamında kullanılan "ede" kelimesini Suriyeli Beşşar için de kullanmaya başlamışlardır. Beşşar'1 oyunlara ismiyle değil bu kelimeyle davet etmişlerdir. Bir süre sonra Beşşar'da Türk erkek çocuklarına bu şekilde seslenmiştir. Beşşar'ın Türk erkek grubuna dâhil olduktan sonra 
B. Yanık Özger ve H, Kozandağı / Pamukkale Üniversitesi Eğitim Fakültesi Dergisi, 51, 299-326, 2021311 Türkçe "Hayır, bak, bir dakika, onu bana ver, ne zaman bahçe gidecek" şeklinde sözcük ve basit cümleler kullanmaya başladığı gözlenmiştir. Beşşar ile ilişkili örnek bir durumu açıklayan gözlem ve görüşme notu aşağıda verilmiştir:

Türk erkek çocuklar ahşap bloklarla kule, ev, çiftlik yapıyordu. Emir, Beşşar' 1 aralarına "Ede, gel hadi " şeklinde seslenerek davet etti. Beşşar oyun hamuru ile oynuyordu, hemen kaldırıp onların yanına gitti. Bloklardan alıp onlara bakarak yaptıklarının aynısını yapmaya çalıştı. Emir ise cebinden arabasını Beşşar'ın oynadığı bloklarının içinden geçirerek sürmeye başladı. Bunu yaptıktan sonra Beşşar ile gülüşüyorlard1. (Gözlem, 02.04.2019)

Araştırmacı - Beşşar sana nasıl sesleniyor?

Emir -İsmimi de söylüyor. Ede de diyor.

Araştırmacı- Ede ne demek?

Emir -Arkadaşım

Araştırmacı -Beşşar’a ede demesini kim öğretti?

Emir - Ali (Görüşme, 03.05.2019).

Beşşar'ın Türk erkek çocukları ile olan yakın ilişkilerini gösteren çizimler aşağıda sunulmuştur:

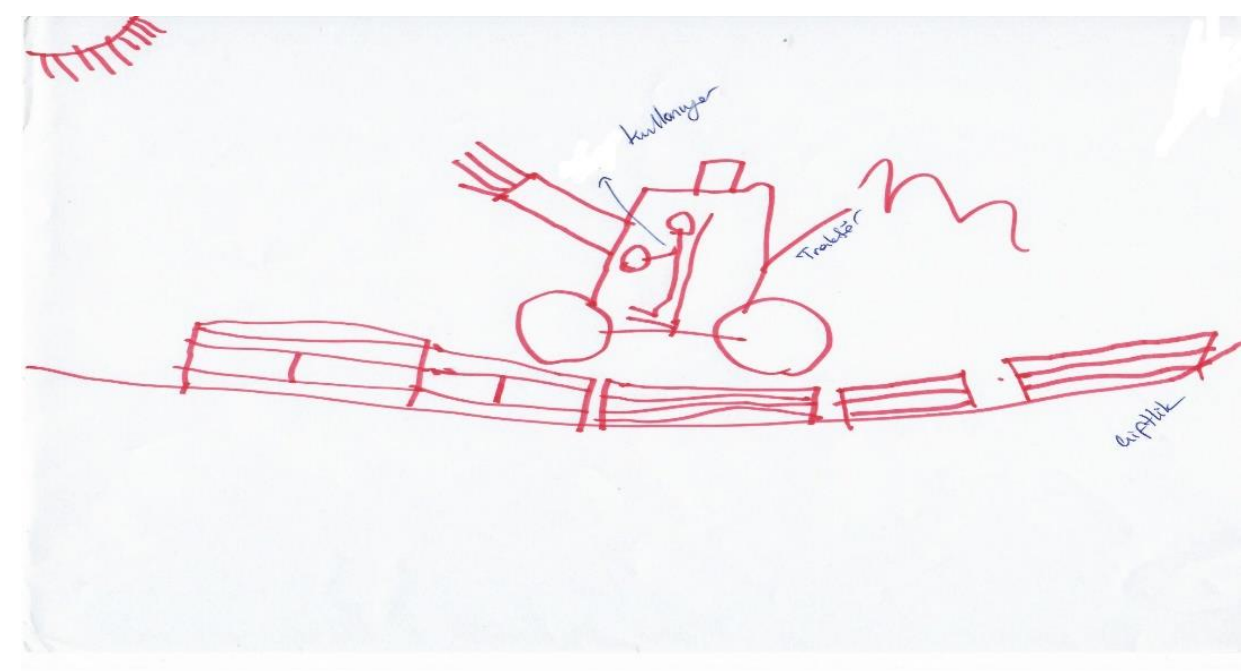

Şekil 1. Beşşar çiftlikte traktör kullanıyor (Emir'in çizimi) 


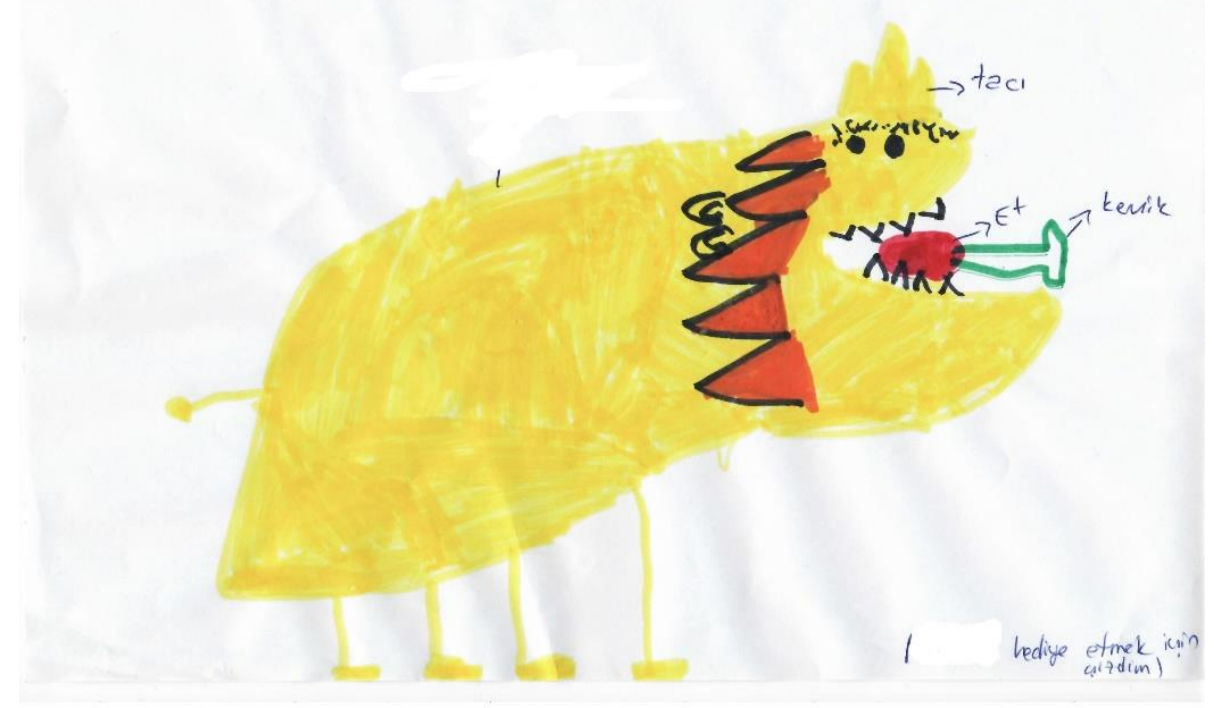

Şekil 2. Beşşar için çizilmiş bir aslan (Mustafa'nın çizimi)

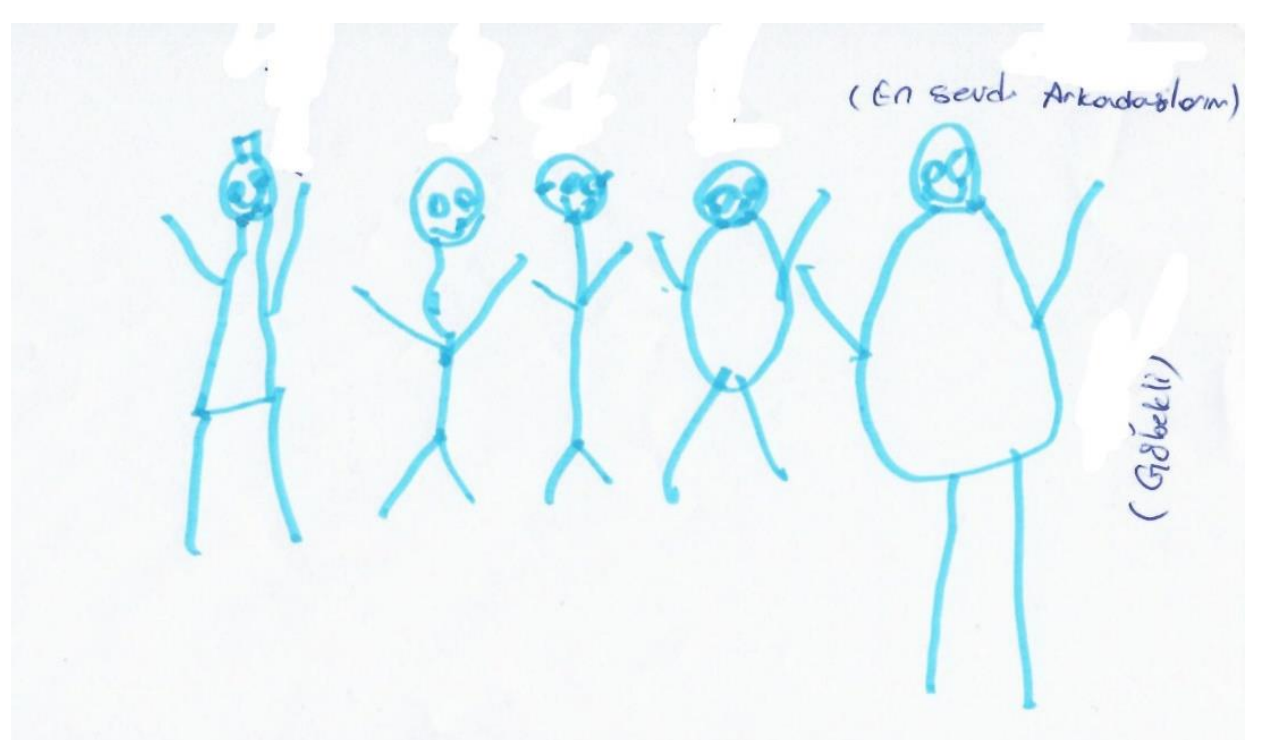

Şekil 3. Beşşar'ın sevdiği arkadaşları (Mustafa, Yusuf, Eren, Fatma, Oğuz yer almakta)

Sınıftaki Türk ve Suriyeli çocukların her zaman yakın ilişkiler kurması ve birbirlerinin oyunlarına katılmaları mümkün olmamıştır. Türk çocuklardan bazıları Suriyeli çocukları oyunlarına kabul etmemiş ve "Sen oynamıyorsun!" şeklinde iterek dişlamışlardır. Türk çocuklarla yapılan görüşmelerde Suriyeli çocuklarla neden oynamadıkları sorulduğunda onları anlamadıkları için oyuna almadıklarını dile getirmişlerdir. Buna ilişkin örnek görüşme notları aşağıda verilmiştir: 
Araştırmacı -Bir oyun kursaydın bu oyunda kimler yer almazdı?

Ela-Suriyeliler.

\section{Araştırmacı-Neden?}

Ela- Suriyelileri sevmiyorum.

Araştırmacı -Neden sevmiyorsun?

Ela- Çünkü onlar Türkçe konuşamıyor. Ben onların sesini duyamıyorum.

Araştırmacı - Onları anlasaydın arkadaş olmak ister miydin?

Ela- Evet. (Görüşme, 07.05.2019)

Araştırmacı- Bir oyun kursaydın bu oyunda kimler yer almazdı?

Hatice -Suriyeliler.

\section{Araştırmacl--Neden?}

Hatice -İşte, anlamıorum.

Araştırmacı- Onları anlasaydın arkadaş olmak ister miydin?

Hatice - Evet, Merva ile. (Görüşme, 07.05.2019)

Çocuklar arasında yaşanan bu dışlamalar yalnızca Suriyeli çocuklara yönelik gerçekleşmemiştir. Bazı Türk ve Suriyeli çocuklar kendilerinden olan çocukları dışlayarak oyunlarına kabul etmemişlerdir. Oyundan dışlanan bu çocuklar aynı dili konuşmadıkları diğer grupların oyunlarına katılmışlardır. Buna göre Suriyeli yaşıtları tarafindan oyundan dışlanan Suriyeli çocukların Türk çocukların oyunlarına, Türk arkadaşları tarafından oyundan dışlanan Türk çocukların ise Suriyeli çocukların oyunlarına katıldıkları gözlenmiştir. Türk çocuklardan Azra, Nurdan, Oğuz ve Ela Suriyeli çocuklarla diğer çocuklardan daha fazla iletişim kurarken, Suriyeli çocuklardan Merva ise Türk çocuklarla oyun oynamıştır. Çocuklara birlikte oynadıkları arkadaşları sorulduğunda Türk çocukları Suriyeli çocuklar arasından Merva'nın ismini, Suriyeli çocuklar ise Azra ve Nurdan'ın adlarını vermişlerdir. Buna ilişkin örnek görüşme notları aşağıda verilmiştir:

Araştırmacı-Bir oyun kursaydın bu oyunda kimler yer alırdı?

Fatma-Rand, Merva, Henedi, Nurdan (Türk), Ayten.

Araştırmacı- Birlikte oynadığın Türk arkadaşın var mı? 
Fatma-Nurdan, Azra. (Görüşme, 10.05.2019)

Araştırmacı- Bir oyun kursaydın bu oyunda kimler yer alırdı?

Henedi- Beşşar, Ayten, Rand, Fatma, Nurdan, Merva. (Görüşme, 10.05.2019)

\section{Türk ve Suriyeli Çocukların Oyun İlişkilerinde Rol Oynayan Unsurlar}

Türk ve Suriyeli çocukların oyun ilişkilerini şekillendiren unsurlar öğretmenin ve ailelerin Suriyeli çocuklara karşı yaklaşımı olmuştur. Öğretmenin sınıftaki bütünleştirici etkinlikleri Türk çocukların Suriyeli çocuklarla oyun ilişkisini artırırken, Türk ailelerden bazılarının Suriyeli çocuklara olumsuz bakış açısı çocukların oyun ilişkilerini zayıflatmıştır.

Öğretmenin Suriyeli çocuklara karşı 1lımlı ve sevecen yaklaşımı, sınıftaki etkinliklerde çocukları bir araya getirici oyunlar planlaması olumlu ilişkilerin kurulmasında rol oynamıştır. Öğretmen Suriyeli çocuklarla yakın ilişkiler kurarken çocukların da birbiriyle yakınlaşmasını ve serbest oyunlarında da bir araya gelmesini sağlamıştır. Aşağıda Şekil 4'te Suriyeli Rand'ın öğretmenini balık olarak resimleyip sevgisini dile getirdiği çizim sunulmuştur:

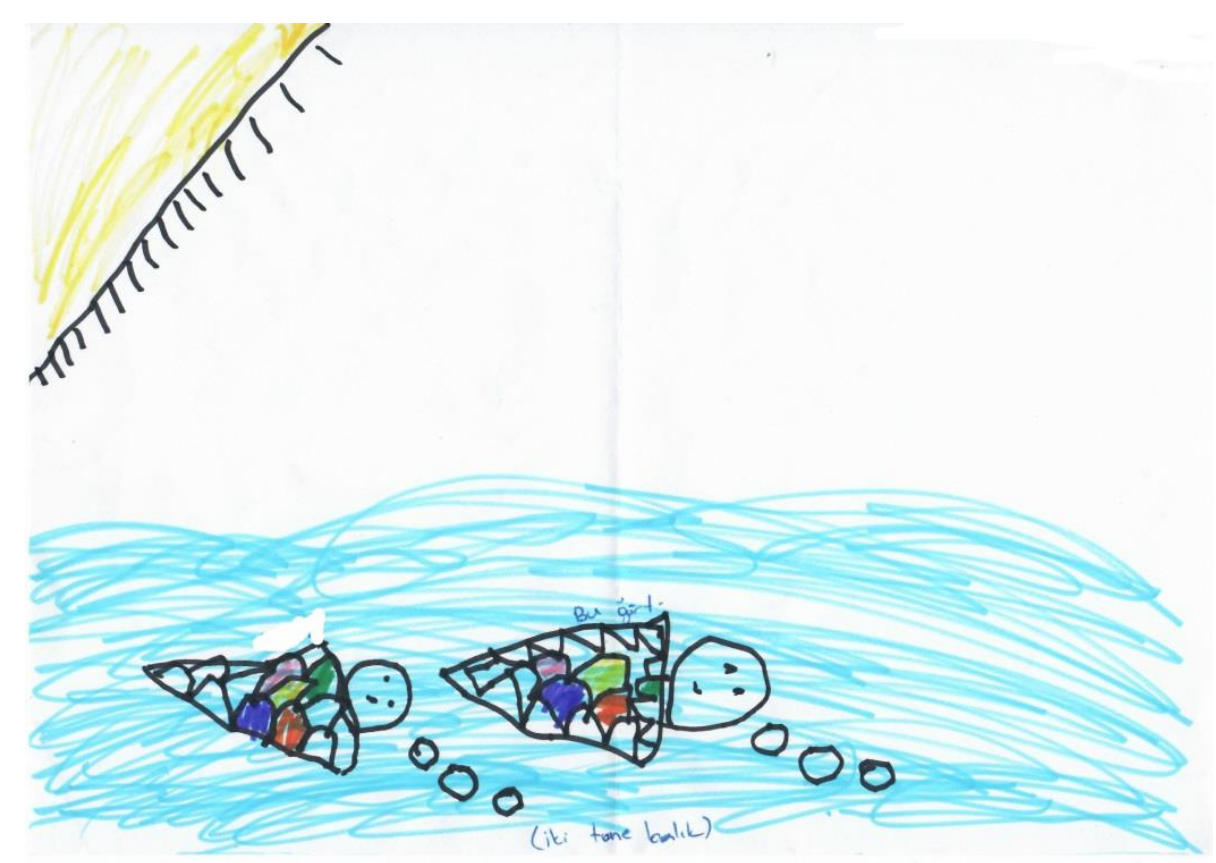

Şekil 4. Rand ve ögretmeni

Öğretmen, yalnızca kendi ilişkilerini değil aynı zamanda Türk ve Suriyeli çocukların iletişimlerini ilerletmeleri için de çaba göstermiştir. Suriyeli çocuklarla ilgili olumlu 
B. Yanık Özger ve H, Kozandağı / Pamukkale Üniversitesi Eğitim Fakültesi Dergisi, 51, 299-326, 2021315 söylemlerde bulunmuş ve Türk çocukların da bu yönde düşünmesini istemiştir. Diğer yandan onların bir araya gelebilmeleri için grup etkinlikleri planlamıştır. Bunu en iyi örnekleyen sınıfta tek erkek Suriyeli olan Beşşar'ın hikâyesidir. Türkçe bilmeyen Beşşar, okul başladığı ilk günden itibaren Suriyeli kız çocuklarının evcilik türü oyunlarına katılmış ve sınıftaki Türk erkek çocuklarıyla oynama girişiminde bulunmamıştır. Beşşar’ın etkinliklerdeki renk seçimlerinin pembe ağırlıklı olması ve oyunlarda çoğunlukla bebekleri tercih etmesi öğretmenin dikkatini çekmiştir. Beşşar'ın Türk erkeklerin etkinliklerine katılmayı tercih etmediği tutulan gözlem notlarında ağırlık kazanmıştır. Buna ilişkin örnek durumu açıklayan gözlem notu aşağıda verilmiştir:

Bugün Türk erkek çocuklar kendi aralarında kurtçuluk oynadılar. Kurt sürüsü gibi uluyup durdular. Beşşar ise bu oyuna katılmayıp hiç oralı olmadı, onun yerine Barbie bebekle oynamayı tercih etti. (Gözlem, 07.03.2019)

Suriyeli Beşar'ın sınıftaki oyun ilişkisi ve tercihleri iki araştırmacı arasında tartışma konusu olmuştur. Araştırma süresince yapılan tartışmalar ve gözlemler Beşşar'ın sınıftaki tek erkek Suriyeli olmasının oyun ilişkilerinin şekillenmesinde rol oynadığı ihtimalini gündeme getirmiştir. Bunun üzerine sınıfta Suriyeli Beşşar'1 Türk erkekleriyle bir araya getiren yapılandırılmış etkinlikler düzenlenmiştir. Öğretmen sınıfta grup etkinlikleri yaparak Beşşar'ın Türk erkekleriyle iletişime geçmesinde rol oynamıştır. Bununla ilişkili örnek bir durumu anlatan gözlem notu aşağıda verilmiştir:

Sınıfa geldiğimde Beşşar ve Emir legolarla kule yapma oyunu oynuyordu. Oyunda amaç sırayla legoyu üst üste koyup en uzun kuleyi yapmaktı. Kuleyi birlikte yaptıktan sonra bana göstermek için yanıma geldiler ve Emir 'Öğretmenim, bak birlikte yaptık biz.' şeklinde diyerek kulelerini gösterdiler. (Gözlem, 19.03.2019)

Beşşar, Emirle başlayan ilişkisinden sonra Suriyeli kız çocuklarıyla olan oyunlarını azaltmış ve Türk erkek çocuklarının oyunlarına dâhil olmaya başlamıştır. Süreç ilerledikçe Türk çocukları da Beşşar'ı aralarına kabul ederek oyunlarına davet etmişlerdir. Beşşar Türk çocuklardan Emir'i kendisine yakın arkadaş olarak seçmiş ve birbirlerini arkadaş anlamına gelen "ede" kelimesiyle çağırmaya başlamışlardır. Öğretmenin Suriyeli çocuklara olan pozitif yaklaşımı da çocukların oyun ilişkilerini değiştirmiştir.

Türk çocuklarının düşüncelerini doğrudan ya da dolaylı olarak şekillendiren bir diğer unsur aileler olmuştur. Türk ailelerden bazıları Suriyeli çocuklara karşı ön yargılı yaklaşmışlardır. Okulun ilk zamanları Türk ailelerden birisi sınıftaki Suriyeli çocuk sayısını yüksek bularak 
çocuğunun kaydını başka bir okula aldırmıştır. Buna ilişkin Türk bir babayla yapılan görüşme notları aşağıda verilmiştir:

Araştırmacı- Okula gönderirken herhangi bir tereddüdünüz oldu mu?

Azra'nın Babası- Benim bir tereddüdüm olmadı ama annesinin oldu.

Araştırmacı- Ne gibi oldu?

Azra'nın Babası -Kültürel farktan dolayı. Çok farklıyız yani; onların kültürleri farklı

bizimki farklı. Bizimle aynı değiller. Yaşam tarzları farklı. (Görüşme, , 03.05.2019)

Suriyeli çocuklara karşı ön yargılı olan Türk ailelerin çocukları da sınıfta dışlayıcı davranışlar sergilemişlerdir. Suriyeli çocuklarla oyun oynamak istememiş ya da hiç iletişim kurmamışlardır. Öğretmen sınıftaki bu durumu ortadan kaldırabilmek için her zaman Suriyeli çocuklarla ilgili olumlu söylemlerde bulunmuştur. Öğretmenin bu tutumu Türk çocukların Suriyeli çocuklara karşı davranışlarının değişmesinde rol oynamıştır. Türk çocuklardan Ali okulun ilk zamanlarında yalnızca Türk çocuklarıyla oynamayı tercih etmiş, sınıftaki Suriyeli çocukları isimleri anmamıştır. Bununla ilişkili örnek bir durumu açıklayan gözlem ve görüşme notları aşağıda verilmiştir:

Dün Ali oyununu bırakıp yanıma geldi ve Suriyeli çocuklardan Ayten'i “Öğretmenim, Suriyeliler bizim oyunumuzu bozuyor!” şeklinde şikâyet etti. Ben de ona o arkadaşının bir ismi olduğunu ve ondan bahsederken ismini kullanması gerektiğini söyledim. Birisinin kendisine bu şekilde davrandiğ 1 takdirde nasıl hissedeceğini sordum. (Gözlem, 06.03.2019)

Araştırmacı- Ali'nin Suriyeli çocuklarla ilişkisi nasıl?

Ali’nin annesi- Benimki fazla muhatap olmuyor. Onlarla anlaşamıyor çünkü.

Araştırmacı-Peki neden anlaşamıyor?

Ali’nin annesi- Bilmiyorum. Benim biraz evde de kayınbabam biraz eşim olsun savaş bitti artık Suriyeliler gitsinler gibisinden konuşuyor. Ailede çok fazla şey olmadığı için herhalde çocuklar da istemiyorlar Suriyelilerle beraber olmayı. (Görüşme, 03.05.2019)

Eren ve Ali birlikte oynarken aralarında şu şekilde konuşmalar geçti.

Eren- Ben büyüyünce asker olacağım. Çünkü Suriye’ ye gidip oradaki düşmanlarla savaşacağım. 
Ali- Ben de teröristlerle savaşacağım. Çünkü onlar bizim paramızı azaltıyor! Özel dürbünlü silahlarla teröristleri vuracağım. (Gözlem, 20.02.2019)

Aşağıda Şekil 5'te sunulan Ali’nin çiziminde Suriyeli çocuklara yer vermediği görülmektedir:

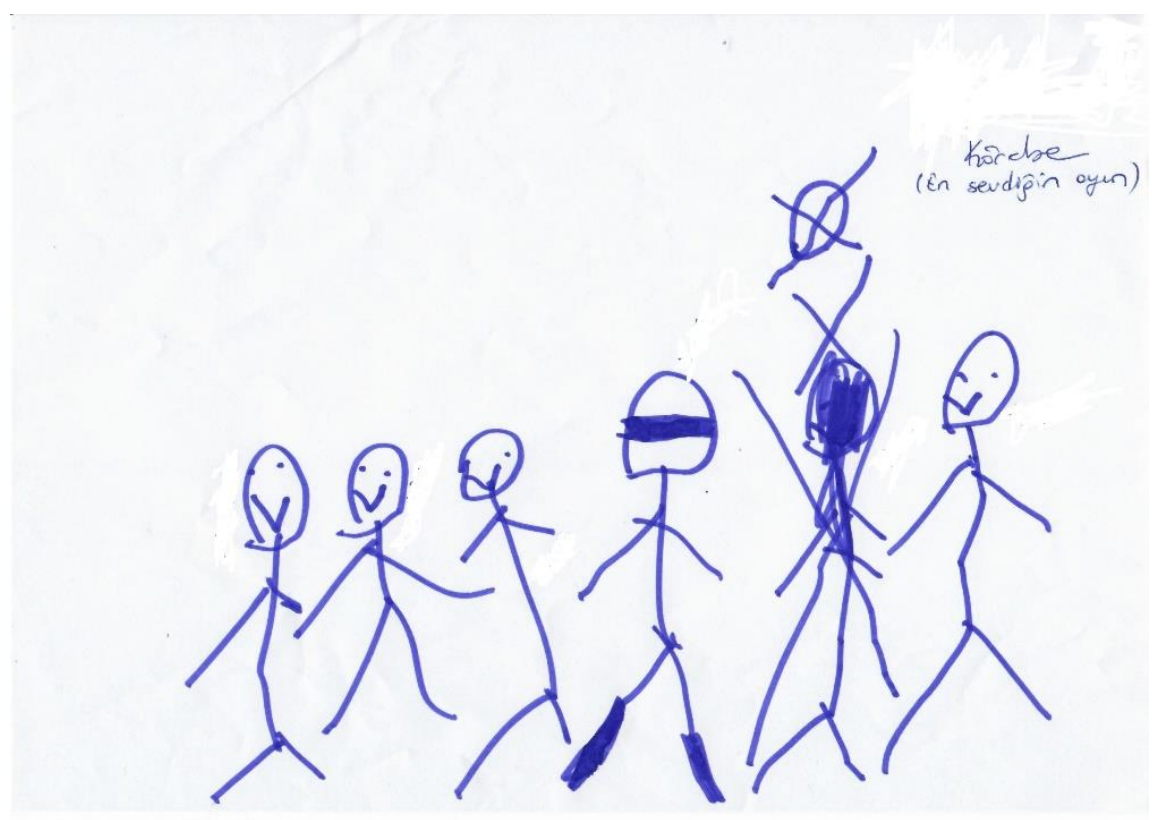

Şekil 5. Körebe oyunu (Mustafa, Emir, Mevlüt, Nurdan, Ŏguz, Yusuf yer almaktadır)

Ali, öğretmeniyle olan ilişkisine zarar gelmemesi için bir süre sonra Suriyeli çocuklara iyi davranmaya başlamış ve bunu da öğretmenine göstermiştir. Diğer çocukların Suriyeli Rand ile dalga geçtiği bir gün öğretmenine "Öğretmenim Rand ile dalga geçiyorlar. Başkalarıyla dalga geçilmesini istemem" şeklinde savunmuş ve ilerleyen zamanlarda Beşşar ile oyun arkadaşlığı kurmuştur. Ali ve sınıftaki bazı çocuklar Suriyeli akranlarıyla olan ilişkilerini ailelerine hiç bahsetmemiş ya da onlarla olan arkadaşlığını açıkça savunmuşlardır. Bununla ilişkili yapılan görüşme notları aşağıda verilmiştir:

Araştırmacı-Evde hiç Suriyeli çocuklardan bahsediyor mu?

Ali’nin annesi-Ali evde hiç bahsetmiyor. Onlarla fazla bir diyaloğu olmadığı için onlar hakkında konuşmuyor (Görüşme, 03.05.2019).

Araştırmacı- Evde Suriyeli çocuklarla ilgili olumsuz yorumlar yapılıyor mu?

Mustafa'nın annesi -Ben demiyorum fakat babaannesi ve anneannesinden duyuyor.

Araştırmacı- Mustafa bu konuşmalara ne tepki veriyor? 
Mustafa'nın annesi -Mesela Suriyelilerin bir şeyinden, 'pis' diyorlar ya, Mustafa

“Hayır öyle değil!, Beşşar benim arkadaşım” diyor. (Görüşme, 03.05.2019)

\section{Tartışma}

$\mathrm{Bu}$ araştırma, bir okul öncesi sınıfındaki Türk ve Suriyeli çocukların oyunlarını ve oyundaki ilişkilerini incelemiştir. Elde edilen bulgular, mülteci çocukların okulun ilk zamanları kendi gruplarıyla vakit geçirirken, ilerleyen zamanlarda Türk çocuklarının oyunlarına dâhil olduklarını, birlikte oyun ve yakın arkadaşlıklar kurabildiklerini göstermiştir. Bu durum Rogoff'un (2003; 1990), kültür ve insan gelişimi teorisine göre değerlendirildiğinde çocukların gelişimsel bir süreç gösterdiği anlaşılmaktadır. Rogoff (2003; 1990), bireyin gelişiminin katılımcı olduğu sosyokültürel aktivitelerdeki rolünün değişimiyle gerçekleştiğini vurgulamaktadır. Bu sebeple kültürel süreç içerisinde kurulan ilişki ve aktiviteler önemlidir (Rogoff, Baker- Sennett, Lacasa ve Goldsmith, 1995). Bu araştırmada da Türk ve Suriyeli çocukların sosyokültürel bir aktivite olan oyun içerisindeki rollerinde değişim gözlenmiştir. Türk ve Suriyeli çocukların birlikte oyun kurmaya başlaması, Suriyeli Rand'ın diğer çocuklar tarafından oyunda lider olarak kabul edilmesi ve Suriyeli Beşşar'ın Türk erkek çocukları grubuna dâhil olması rollerdeki bu değişimi göstermektedir.

Bu araştırmadaki Türk ve Suriyeli çocuklar ilişkilerini beden dilini kullandıkları basit kuralları olan oyunlar içerisinde ilerletmişlerdir. Yapılan bir araştırmada mülteci çocukların Türk çocuklarla oyun zamanı kaynaştıkları ifade edilmiştir (Çakan, Mercan ve Uzun, 2018). Rutter (2006), mülteci çocuklar için ırkçılığın olmadığı, psikososyal ihtiyaçlarının karşılandığı çevrenin önemine vurgu yapmaktadır. Bu araştırmada da oyun mülteci çocuklar için samimi bir çevrenin oluşmasına zemin hazırlamıştır. Oyun, çocukların akranlarıyla etkileşim içerisine girmesine, iletişim becerilerinin artmasına ve duygusal destek sağlamasına katkı sunmaktadır (Cross, 2011). Bu araştırmada da Suriyeli Beşşar'ın Türk çocuklarının grubuna dâhil olduktan sonra Türkçe kelimelerinde artış yaşandığı gözlenmiştir.

Suriyeli ve Türk çocukların akran ilişkilerindeki ilerlemeler bir süre sonra statü ve hiyerarşi yarışlarının başlamasına neden olmuştur. Corsaro (2015), çocukların devamlı olarak birbirleriyle yarıştığını, toplumsal ve kişisel becerilerini kullanarak diğerleri üzerinde kontrol kurmaya çalıştıklarından bahsetmektedir. Bu araştırmada Suriyeli çocuklardan Rand diğer çocuklar üzerinde kontrol kurarak oyunları yönetmiş ve Türk çocuklardan Ali ile liderlik yarışına girmiştir. 
B. Yanık Özger ve H, Kozandağı / Pamukkale Üniversitesi Eğitim Fakültesi Dergisi, 51, 299-326, 2021319

Sınıftaki liderlik yarışının yanı sıra düşük statüde bulunan çocuklar da bu araştırma sürecinde öne çıkmıştır. Düşük statülü çocuklar, akranları tarafından gruba ya da oyuna alınmayarak reddedilen çocuklar olarak kabul edilmektedir (Ramsey, 1991). Reddedilmiş çocuklar, saldırgan ya da kendini geri çeken şeklinde iki türlü kendini göstermektedir. Bu araştırmada Türk çocuklar tarafından reddedilen ve oyuna girmesine izin verilmeyen Suriyeli çocuklar olmuştur. Yapılan araştırmalar mülteci çocukların sosyal dışlanma ve ayrımcılığa diğer çocuklardan daha fazla maruz kaldığını göstermektedir (Berry, 1997; Guo, Maitra ve Guo, 2019; Kağnıcı, 2017; McBrien, 2005; Yanık Özger ve Akansel, 2019). Dil problemi mülteci çocukların dışlanmasına ve oyunlarda yalnız kalmasına neden olan faktörler arasında yer almaktadır (Karaağaç ve Güvenç, 2019; Peterson, Meehan, Ali ve Durrant, 2017; Troesch, Keller ve Grob, 2016; Uzun ve Bütün, 2016). Bu araştırmada da Suriyeli çocukların dil engeli Türk çocuklarla olan oyunların içeriğini kısıtlamıştır. Çocuklar daha çok beden dilini kullandıkları oyunlara ağırlık verirken, Türk çocuklardan bazıları dilini anlamadığı gerekçesiyle Suriyeli çocukları oyunda istememişlerdir. Bu durumdaki çocuklar iletişim kurabilmek için diğer çocuklarla çatışmaya girmekte ya da onlardan kendini geri çekmektedir (Rubin, Bukowski ve Parker, 2006). Bu araştırmada da reddedilen çocuklar kendini geri çekerek dilini bilmedikleri Suriyeli veya Türk çocukların grubuna katılmışlardır.

Oyunlarda bir araya gelen Türk ve Suriyeli çocuklar ilişkilerini ve oyunlarını kültürel unsurlar etrafinda yapılandırmışlardır. Van Ausdale ve Feagin (2001) okul öncesinde yapmış oldukları araştırmalarında çocukların birbiriyle etkileşimlerinde ve oyunlarında etnik ve ırksal işaretleri kullandıklarını gözlemlemişlerdir. $\mathrm{Bu}$ çalışmada da Türk çocukların oyunlarında Arapça şarkılar söylediği, Suriyeli çocukların yerel dilde arkadaş anlamına gelen “ede” kelimesini kullandıkları gözlenmiştir.

Çocukların akranlarıyla olan etkileşiminde öğretmenle kurulan ilişki de önem arz etmektedir. Öğretmeniyle kendini güvende hisseden, pozitif bir ilişki kurabilen çocuklar daha az saldırgan ve sosyal olabilirken, çatışmacı bir ilişki akranları da birbirinden uzaklaştırabilmektedir (Howes,Guerra, Fuligni, Zucker,Lee, Obregon ve Spivak, 2011; Howes ve Spieker, 2008). Szente, Hoot ve Taylor (2006), öğretmenin pozitif bir vücut diline sahip olmasının mülteci çocuklar açısından önemli olduğunu vurgulamışlardır. Yapılan araştırmalarda okul öncesi öğretmenlerinin çok kültürlü eğitime yönelik tutum düzeylerinin olumlu olduğu anlaşılmıştır (Danacı, Nuray, Çetin, Pınarcık ve Bahtiyar, 2016; Taştekin, Yükçü, İzoğlu, Güngör, Uslu ve Demircioğlu, 2016). Bu araştırmada da öğretmenin çok 
kültürlü sınıfa karşı pozitif düşünce yapısı ve mülteci çocuklarla yakın ilişkiler kurması Türk çocuklarının dışlayıcı davranışlarını azaltmıştır.

Öğretmenin mülteci çocuklara olan yaklaşımının yanı sıra ailelerin tutumu da çok kültürlü sınıflarda belirleyici olmuştur. Yapılan çalışmalar yerli ailelerin sınıftaki mülteci çocuklara karşı dışlayıcı ve ayrımcı bir tutum sergilediklerini ortaya koymaktadır (Uzun ve Bütün, 2016; Yanık Özger ve Akansel, 2019). Aileler, çocuklarının mülteci çocuklarla aynı sınıfta bulunmasını istemeyerek farklı okullara göndermeyi tercih etmişlerdir (Entzinger ve Biezeveld, 2003). Bu araştırmada da Türk ailelerden bir kısmı Suriyeli çocuklara karşı ön yargılı yaklaşarak çocuklarının dışlayıcı bir tutum sergilemelerinde rol oynamıştır.

\section{Sonuç ve Öneriler}

$\mathrm{Bu}$ araştırmada Suriyeli ve Türk çocuklar birlikte oyun kurarak arkadaşlık ilişkilerini ilerletmişlerdir. İlerleyen ilişkiler sonucunda sosyal dışlanmalar ve liderlik yarışları ön plana çıkmıştır. Çocukların oyun ilişkilerinde rol oynayan unsurlar öğretmen ve ailelerin yaklaşımı olmuştur. Araştırmadan elde edilen bu sonuçlar bir okul öncesi sınıfındaki 18 çocuk ve 8 ailenin katılımıyla elde edilmiştir. Araştırmacılardan yalnızca birinin Arapça temel kelimeleri biliyor olması da bu araştırmanın sınırlılıkları arasında yer almıştır. Araştırmadan elde edilen sonuçlara göre aşağıdaki öneriler sunulmuştur:

- Sınıfta pozitif ilişkilerin gelişmesi için öğretmenler mülteci çocuklara 1lımlı ve sevecen yaklaşmalıdır.

- Öğretmenler, okul başlamadan önce Türk aileleri dinlemeli ve var olan kaygılarını gidermelidir.

- Okul öncesindeki mülteci çocuklarla ilgili etnografik araştırma sayısı artırılmalıdır. 
B. Yanık Özger ve H, Kozandağ1 / Pamukkale Üniversitesi Eğitim Fakültesi Dergisi, 51, 299-326, 2021321

\section{Kaynakça}

Alba, R. D. (2013). Children of immigrants at school: A comparative look at integration in the United States and Western Europe. New York: University Press.

Bačáková, M. (2011). Developing inclusive educational practices for refugee children in the Czech Republic. Intercultural Education, 22(2), 163-175.

Berry, J. W. (1997). Immigration, acculturation and adaptation. Applied Psychology: An International Review, 46, 5-68.

Bjorck-Akesson, E. M. \& Brodin, J. M. (2005). Diversity of aspects on play in children with profound multiple disabilities. Early Child Development and Care, 175(7-8), 635646.

Corsaro, W. A. (2015). The soctology of childhood (4th ed.). California: Pine Forge Press.

Creswell, J. W. (2018). Nitel araştırma yöntemleri: Beş yaklaşıma göre nitel araştırma ve araştırma deseni. (4.Baskı). M. Bütün ve S.B. Demir (Çev.). Siyasal Kitapevi: Ankara.

Cross, M. (2011). Children with social, emotional and behavioural difficulties and communication problems (2th ed.). London, England: Jessica Kingsley Publishers

Çakan, A., Mercan, M. ve Uzun, E. M. (2018). Okul öncesi kurumlarına devam eden mülteci çocukların sosyal-duygusal gelişimleri. V. Özpolat (Ed.). Zorunlu Göçler Ve Doğurduğu Sosyal Travmalar, (s. 267-297), Samsun Valiliği Bilim Kültür Hizmeti.

Danacı, M. Ö., Eran, N., Çetin, Z., Pınarcık, Ö. ve Bahtiyar, M. (2016). Okul öncesi ögretmenlerinin çok kültürlü eğitime yönelik tutumları. Hacettepe Üniversitesi Sağllk Bilimleri Fakültesi, 3 (2), 73- 86.

Entzinger, H., \& Biezeveld, R. (2003). Benchmarking in immigrant integration: Report for the European Commission Immigration and Asylum Committee, Rotterdam, European Research Centre on Migration and Ethnic Relations.

Erickson, F. (1984). What makes school ethnography 'ethnographic'?. Anthropology \& Education Quarterly, 15 (1), 51-66.

Eslek, D. ve Irmak, T. Y. (2018). Ekolojik sistemler kuramı çerçevesinde göçmen çocuklar ve oyunları üzerine bir derleme. Dokuz Eylül Üniversitesi Sosyal Bilimler Enstitüsü Dergisi, 20(3), 347-362. 
Gencer, T. E. (2017). Göç ve eğitim ilişkisi üzerine bir değerlendirme: Suriyeli çocukların eğitim gereksinimi ve okullaşma süreçlerinde karşılaştıkları güçlükler. Journal of International Social Research, 10(54), 838-851.

Gleave, J., \& Cole-Hamilton, I. (2012). A world without play: A literature review. [Available online at: http://www.playengland.org.uk/media/371031/a-world-withoutplay-literature-review-2012.pdf], Retrieved on December 17, 2019

Glesne, C. (2012). Nitel araştırmaya giriş. A. Ersoy ve P. Yalçınoğlu (Çev.). Ankara: Anı Yayıncilik.

Guo, Y., Maitra, S., \& Guo, S. (2019). I belong to nowhere: Syrian refugee children's perspectives on school integration. Journal of Contemporary Issues in Education, 14(1), 89-105.

Howard, T. C. (2001). Telling their side of the story: African-American students' perceptions of culturally relevant teaching. The Urban Review, 33(2), 131-149.

Howes, C., \& Spieker, S., (2008). Attachment relationships in the context of multiple caregivers. J. Cassidy \& P.R. Shaver (Eds.). Handbook of attachment theory and research (p.317-332), Guilford, New York, NY.

Howes, C., Guerra, A. W., Fuligni, A., Zucker, E., Lee, L., Obregon, N. B., et.al. (2011). Classroom dimensions predict early peer interaction when children are diverse in ethnicity, race, and home language. Early Childhood Research Quarterly, 26(4), 399-408.

Hoyte, F., Torr, J., \& Degotardi, S. (2014). The language of friendship: Genre in the conversations of preschool children. Journal of Early Childhood Research, 12(1), 20-34.

Kağnıcı, D. Y. (2017). Suriyeli mülteci çocukların kültürel uyum sürecinde okul psikolojik danışmanlarına düşen rol ve sorumluluklar. İlköğretim Online, 16 (4), 1768-1776.

Kardeş, S. (2018). Mülteci çocukların psikososyal gelişimine yönelik program uyarlanmast. Yayımlanmamış doktora tezi Hacettepe Üniversitesi Eğitim Bilimleri Enstitüsü, Ankara.

Karaağaç, F.C., ve Güvenç, H. (2019). Resmi ilkokullara devam eden Suriyeli mülteci öğrencilerin eğitim sorunları. Uluslararası Toplum Araştırmaları Dergisi, 11(18), $532-568$. 
B. Yanık Özger ve H, Kozandağı / Pamukkale Üniversitesi Eğitim Fakültesi Dergisi, 51, 299-326, 2021323

Karakuş, M. (2019). Views of teachers and students on the problems of Syrian children in a refugee school in Turkey. International Journal of Education and Literacy Studies, $7(2), 211-219$.

Lunneblad, J. (2017). Integration of refugee children and their families in the Swedish preschool: Strategies, objectives and standards. European Early Childhood Education Research Journal, 25(3), 359-369.

Lincoln, Y. S., \& Guba, E. G. (1985). Qualitative inquiry. Thousand Oaks, CA.

MacMillan, K. K., Ohan, J., Cherian, S., \& Mutch, R. C. (2015). Refugee children's play: Before and after migration to Australia. Journal of Paediatrics and Child Health, 51(8), 771-777.

Maurice, V.J., \& Roßbach, H. G. (2017). The educational system in Germany. Korntheuer, Annette, Pritchard, Paul \& Maehler, Débora B. (Eds.), In Structural context of refugee integration in Canada and Germany, (pp. 49-58). Köln: GESIS.

McBrien, J. L. (2005). Educational needs and barriers for refugee students in the United States: A review of the literature. Review of Educational Research, 75(3), 329-364.

MEB, (2018). Geçici koruma kapsamı altındaki ögrencilerin ĕgitim hizmetleri. [Çevrim-içi: https://hbogm.meb.gov.tr/meb_iys_dosyalar/2018_12/03175027_03122018_Yntern et_BYlteni.pdf], Erişim tarihi: 16.12.2019.

Merriam, S. B. (2015). Nitel araştırma: Desen ve uygulama için bir rehber (3.Baskı). S.Turan (Çev.). Nobel Yayınevi: Ankara.

Miles, M. B., \& Huberman, A. M. (1994). Qualitative data analysis: An expanded sourcebook. Thousand Oaks, CA: Sage.

Mosselson, J. (2006). Roots \& Routes: A re-imagining of refugee identity constructions and the implications for schooling. Current Issues in Comparative Education, 9(1), 2029.

Özer, Y. Y., Komsuoğlu, A. ve Ateşok, Z. Ö. (2016). Türkiye'deki Suriyeli çocukların eğitimi: Sorunlar ve çözüm önerileri. Akademik Sosyal Araştırmalar Dergisi, 4(37), $34-42$.

Peterson, A., Meehan, C., Ali, Z., \& Durrant, I. (2017). What are the educational needs and experiences of asylum-seeking and refugee children, including those who are 
B. Yanık Özger ve H, Kozandağı/ Pamukkale Üniversitesi Eğitim Fakültesi Dergisi, 51, 299-326, 2021 unaccompanied, with a particular focus on inclusion?. A literature review. Canterbury: Canterbury Christ Church University.

Pinson, H., \& Arnot, M. (2007). Sociology of education and the Wasteland of refugee education research. British Journal of Sociology of Education. 28(2), 399-407.

Prior, M. A., \& Niesz, T. (2013). Refugee children's adaptation to American early childhood classrooms: A narrative inquiry. The Qualitative Report, 18(20), 1-17.

Ramsey, P. (1991). Making friends in school: Promoting peer relationships in early childhood. New York: Teachers College Press.

Rogoff, B. (1990). Apprenticeship in thinking: Cognitive development in social context. Oxford University Press: New York.

Rogoff, B. (2003). The cultural nature of human development. USA: Oxford University Press.

Rogoff, B., Bakker-Sennett, J., Lacasa, P. \& Goldsmith, D. (1995). Development through participation in sociocultural activity. New Directions for Child and Adolescent Development, 67, 45-65.

Rubin, K., Bukowski, W., \& Parker, J. (2006). Peers, relationships, and interactions. W. Damon \& R. Lerner (Eds.), Handbook of child psychology. (p.571-645), NY: Wiley Publishers.

Rutter, J. (2006). Refugee children in the UK. Maidenhead: Open University Press.

Sağlam, H. İ. ve Kanbur, N.İ. (2017). Sınıf öğretmenlerinin mülteci öğrencilere yönelik tutumlarının çeşitli değişkenler açısından incelenmesi. Sakarya University Journal of Education, 7(2), 310-323.

Sakız, H. (2016). Göçmen çocuklar ve okul kültürleri: Bir bütünleştirme önerisi. Göç Dergisi, 3(1), 65-81.

Schachner, M. K. (2017). From equality and inclusion to cultural pluralism- evolution and effects of cultural diversity perspectives in schools. European Journal of Developmental Psychology, 3(2), 1- 17.

Shriberg, J. (2010). Advancing teacher development in Colorado Refugee Education Programs. [Available online at: http://springinstitute.org/wp- 
B. Yanık Özger ve H, Kozandağı / Pamukkale Üniversitesi Eğitim Fakültesi Dergisi, 51, 299-326, 2021325 content/uploads/2016/04/executivereporttdrproject.pdf], Retrieved on December 16, 2019.

Szente, J., Hoot, J., \& Taylor, D. (2006). Responding to the special needs of refugee children: Practical ideas for teachers. Early Childhood Education Journal, 34(1), 1520.

Taştekin, E., Bozkurt Yükçü, Ş., İzoğlu, A., Güngör, İ., Işık Uslu, E. A. ve Demircioğlu, H. (2016). Okul öncesi öğretmenlerinin çok kültürlü eğitime yönelik tutumlarının ve algılarının incelenmesi. Hacettepe Üniversitesi Ĕ̆itim Bilimleri Enstitüsü Eğitim Araştırmaları Dergisi, 2(1), 1-20.

Tatlıcıoğlu, O. (2019). Suriyeli çocukların iyi olma hallerinin incelenmesi: Altındă̆ örneği. (Yayımlanmamış doktora tezi). Hacettepe Üniversitesi Sosyal Bilimler Enstitüsü, Ankara.

Taylor, S., \& Sidhu, K. (2012). Supporting refugee students in schools: What constitutes inclusive education?. International Journal of Inclusive Education, 16(1), 39-56.

Troesch, L. M., Keller, K., \& Grob, A. (2016). Language competence and social preference in childhood: A meta-analysis. European Psychologist, 21 (3), 167-179.

UNICEF. (2007). Çocuk hakları ve gazetecilik uygulamaları hak temelli perspektif. Unicef Dublin Teknoloji Enstitüsü.

UNICEF, (2016). Türkiye'de kayıp bir kuşak oluşmasını önlemek. [Çevrim-içi: http://www.unicef.org.tr/files/bilgimerkezi/doc/10.2016_Children\%20of\%20Syria_re vised_TR_final.pdf], Erişim tarihi: 30.01.2020.

Uzun, E. M. ve Bütün, E. (2016). Okul öncesi eğitim kurumlarındaki Suriyeli sığınmacı çocukların karşılaştıkları sorunlar hakkında öğretmen görüşleri. Uluslararası Erken Çocukluk Ĕ̈itimi Çalışmaları Dergisi, 1(1), 72-83.

Van Ausdale, D., \& Feagin,J. (2001). The First R: How children learn race and racism, Lanham, Maryland: Rowman and Littlefield.

Yanık Özger, B. ve Akansel, A. (2019). Okul öncesi sınıfındaki Suriyeli çocuklar ve aileleri üzerine bir etnografik durum çalışması: Bu sınıfta biz de varız!. Eğitimde Nitel Araştırmalar Dergisi, 7(3), 942-966. 
326 B. Yanık Özger ve H, Kozandağı/ Pamukkale Üniversitesi Ĕ̆itim Fakültesi Dergisi, 51, 299-326, 2021

Yin, R. K. (2003). Case study research: Design and methods. (3rd ed.). Thousand Oaks, CA: Sage. 